Abstracta Iranica Abstracta Iranica

Revue bibliographique pour le domaine irano-aryen

Volume 32-33 | 2013

Comptes rendus des publications de 2009-2010

\title{
Sreeramula R. Sarma. Persian-Sanskrit Lexica and the Dissemination of Islamic Astronomy and Astrology and India
}

\section{Živa Vesel}

\section{(2) OpenEdition}

1 Journals

\section{Édition électronique}

URL : http://journals.openedition.org/abstractairanica/40718

DOI : 10.4000/abstractairanica.40718

ISSN : 1961-960X

Éditeur :

CNRS (UMR 7528 Mondes iraniens et indiens), Éditions de l'IFRI

\section{Édition imprimée}

Date de publication : 1 décembre 2013

ISSN : 0240-8910

Référence électronique

Živa Vesel, «Sreeramula R. Sarma. Persian-Sanskrit Lexica and the Dissemination of Islamic Astronomy and Astrology and India », Abstracta Iranica [En ligne], Volume 32-33 | 2013, document 402, mis en ligne le 01 juillet 2016, consulté le 03 octobre 2020. URL : http://journals.openedition.org/ abstractairanica/40718; DOI : https://doi.org/10.4000/abstractairanica.40718

Ce document a été généré automatiquement le 3 octobre 2020.

Tous droits réservés 


\title{
Sreeramula R. Sarma. Persian- Sanskrit Lexica and the Dissemination of Islamic Astronomy and Astrology and India
}

\author{
Živa Vesel
}

\section{RÉFÉRENCE}

Sreeramula R. Sarma. «Persian-Sanskrit Lexica and the Dissemination of Islamic Astronomy and Astrology and India », in : G. Gnoli \& A. Panaino, eds., Kayd. Studies in the History of Mathematics, Astronomy and Astrology in Memory of David Pingree. Rome, IsIAO, 2009, p. 129-150.

1 Les dictionnaires bilingues persan-sanskrit, relativement nombreux, existaient déjà avant le sultanat de Delhi, sur la côte ouest de l'Inde, grâce aux contacts des milieux jaina avec les musulmans. Akbar ayant désigné des hindous comme astronomes royaux, les cours mogholes sont à l'origine des lexiques persan-sanskrit portant également sur l'astronomie et l'astrologie, et importants, entre autres, pour la connaissance du calendrier, des élections (périodes propices ou néfastes), du vocabulaire, etc. La portée de ces lexiques a dépassé la fonction purement utilitaire puisqu'ils semblent avoir servi également à l'enrichissement de la culture des élites hindoues et musulmanes. 


\section{AUTEURS}

ŽIVA VESEL

CNRS, Mondes iranien et indien, Paris 